\title{
Quantitative Microbial Risk Assessment for Escherichia coli in Drinking Water in Bandarharjo Village, Semarang, Indonesia
}

\author{
Vidia Nabilah Putri ${ }^{1}$, Sulistiyani2 ${ }^{2 *}$, Mursid Raharjo ${ }^{3}$
}

1,2,3 Department of Environmental Health, Public Health Faculty, Diponegoro University, Indonesia
*Corresponding author : $\underline{\text { sulistiyani@ live.undip.ac.id }}$

\begin{abstract}
Universal access to safe drinking water is a basic need and a human right. Drinking water contamination can occur in the household. One of the bacteria that can contaminate water is Escherichia coli which can cause gastrointestinal disease. The purpose of this study was to conduct a microbial risk assessment of drinking water contaminated with Escherichia coli bacteria in the Bandarharjo Village. This research is a descriptive study with the Quantitative Microbial Risk Assessment (QMRA) method. The sample in this study consisted of 94 people as subjects and 94 samples of drinking water as object samples. The sampling technique used is proportional random sampling. The results showed that as many as 51drinking water samples (54,3\%) did not meet the requirements. The average intake and frequency of exposure are 1,63 liters and 365 days/year. The results of the QMRA calculation show that the average value of the probability of infection per day and the probability of infection per year are $2,12 \times 10^{-5}$ and 7,7 $\times 10^{-3}$. The research concludes that the probability of infection per year is greater than the acceptable risk by US EPA, which is $10^{-4}$.
\end{abstract}

Keywords-Drinking Water, Escherichia coli, Quantitative Microbial Risk Assessment.

\section{INTRODUCTION}

Water is a natural resource that is very abundant because it can be found in every place on the surface of the earth. The role of water is very important for humans because almost all human activities require water. In addition to the quantity, water quality is no less important to meet the needs of human life. Water that is used in daily life must meet health requirements. ${ }^{(1)}$ According to the Regulation of the Minister of Health of the Republic of Indonesia Number 416 of 1990 concerning Requirements and Supervision of Water Quality, water quality must meet health requirements which include microbiological, physical, chemical, and radioactive. Microbiological parameters for drinking water are fecal coliform and total coliform, each of which is $0 / 100 \mathrm{ml}$ of water. ${ }^{(2)}$

Poor water quality is one of the biggest health and environmental problems in the world. Lack of access to clean water sources is a major risk factor for infectious diseases, including cholera, diarrhea, dysentery, hepatitis A, typhoid, and polio. An estimated 1,2 million people worldwide died from insecure water sources in 2017. As many as $9 \%$ of the world's population does not have access to clean water sources. Clean water sources must provide safe water, but does always guarantee that the water is safe. Examples of sources of clean water are household water pipeline connections, drilled wells, protected dug wells, protected springs, and rainwater collection. ${ }^{(3)}$

The Bandarharjo Village community uses wellbore water to fulfill their daily needs, both for bathing, washing, drinking, and cooking. Based on WHO drinking water standards, groundwater from all sources cannot be used for drinking water and must be treated before consumption. Water sourced from groundwater must be disinfected or cooked before it is used for drinking to avoid contamination. All types of human activities such as agriculture, commercial, industrial, and housing can contribute to groundwater contamination. ${ }^{(4)}$

Some activities that can negatively impact groundwater if not managed properly are the storage of chemicals, accidental spills of hazardous materials, distribution of sludge, sludge, septic systems, animal feeding areas, use and spills of fertilizers and pesticides, landfills or open solid waste disposal and abandoned private wells. $^{(5)}$

In addition to these external factors, drinking water contamination can also occur in the household. Lack of good hygiene practices, such as washing hands after defecation, is a direct route of water contamination in the household. Contamination of hands, equipment, food, and clothing, especially when sanitation and hygiene in poor households can play a role in causing outbreaks of 
sanitation-related diseases such as cholera and typhus. In general, it is difficult to guarantee good water quality outside water sources, because poor sanitation and hygiene practices can result in a significant decrease in water quality from the water collection process until just before consumption. ${ }^{(6)}$

E. coli bacteria is an indicator of water pollutants. This parameter is found in water contaminated by human feces and can cause diarrheal disease. The presence of Escherichia coli bacteria in water makes it able to transmit waterborne diseases. The disease can spread when bathing, washing, drinking water, or eating food exposed to contaminated water. ${ }^{(7)}$

Quantitative Microbial Risk Assessment (QMRA) is a method that can be used to estimate the level of human health risks posed by the contamination of microorganisms by predicting infection rates $/ \mathrm{P}_{\text {infections }}\left(\mathrm{P}_{\text {inf }}\right)$ of certain pathogens, estimates of consumption levels and appropriate dose-response models for exposed populations. The MRA includes not only the possibility of exposure and the impact of exposure but also the steps of planning, hazard identification, and hazard characterization. ${ }^{(8)}$

Based on the facts described above, this study aims to assess the risk of microbes in drinking water contaminated with Escherichia coli bacteria in Bandarharjo Village.

\section{METHODS}

This research is a descriptive study using the Quantitative Microbial Risk Assessment (QMRA) method. The sample in this study consisted of 94 people as subjects and 94 samples of drinking water as object samples. The sampling technique used is proportional random sampling. The independent variables in this study were the number of Escherichia coli, the rate of intake, and the frequency of exposure, while the dependent variable was the risk of $\mathrm{E}$. coli infection

Data analysis was performed using the Quantitative Microbial Risk Assessment (QMRA) method used to estimate the level of human health risks posed by the contamination of certain microorganisms. QMRA is carried out in 4 steps, namely hazard identification, exposure assessment, dose-response analysis, and risk characterization

\section{RESULTS}

Distribution of research data regarding the rate of intake of respondents in the Bandarharjo Village can be seen in the table below.
Table 1. Distribution of Frequency of Respondent Intake Rate in Bandarharjo Village

\begin{tabular}{|c|c|c|c|c|c|c|}
\hline \multicolumn{7}{|l|}{ Intake } \\
\hline $\begin{array}{l}\text { Rate } \\
\text { (liter) }\end{array}$ & $\mathrm{n}$ & $\%$ & Min & Max & Mean & SD \\
\hline 0,25 & 4 & $4,3 \%$ & \multirow{17}{*}{0,25} & \multirow{17}{*}{7,5} & \multirow{17}{*}{1,63} & \multirow{17}{*}{1,05} \\
\hline 0,3 & 1 & $1,1 \%$ & & & & \\
\hline 0,33 & 2 & $2,1 \%$ & & & & \\
\hline 0,5 & 2 & $2,1 \%$ & & & & \\
\hline 0,6 & 6 & $6,4 \%$ & & & & \\
\hline 0,8 & 1 & $1,1 \%$ & & & & \\
\hline 1 & 18 & $19,1 \%$ & & & & \\
\hline 1,2 & 3 & $3,2 \%$ & & & & \\
\hline 1,5 & 19 & $20,2 \%$ & & & & \\
\hline 1,8 & 4 & $4,3 \%$ & & & & \\
\hline 2 & 19 & $20,2 \%$ & & & & \\
\hline 2,4 & 1 & $1,1 \%$ & & & & \\
\hline 2,5 & 1 & $1,1 \%$ & & & & \\
\hline 3 & 10 & $10,6 \%$ & & & & \\
\hline 4,5 & 2 & $2,1 \%$ & & & & \\
\hline 7,5 & 1 & $1,1 \%$ & & & & \\
\hline Total & 94 & $100 \%$ & & & & \\
\hline
\end{tabular}

rate was 1.63 liters per day, with a minimum value of 0.25 liters, a maximum value of 7.5 liters, and a standard deviation of 1.05 . The highest intake rate values are 1.5 liters and 2 liters, which are 19 people (20,2\%) each.

The frequency of exposure is the number of days the exposure occurs in a year. The frequency of respondents' exposure all has the same value, which is 365 days/year (100\%). This shows that exposure occurs every day of the year.

Distribution of research data regarding the bacteriological quality of respondent drinking water in Bandarharjo can be seen in the table below.

Table 2. Distribution of Frequency of Bacteriological Quality of Drinking Water of Respondents in Bandarharjo

\begin{tabular}{cccc}
\multicolumn{4}{c}{ Village } \\
\hline No & $\begin{array}{c}\text { Bacteriological Quality } \\
\text { of Drinking Water }\end{array}$ & $\mathrm{n}$ & $\%$ \\
\hline 1 & Qualify & 43 & $45,7 \%$ \\
2 & Not Qualify & 51 & $54,3 \%$ \\
\hline & Total & 94 & $100 \%$
\end{tabular}

Table 2 shows that 43 samples $(45,7 \%)$ of drinking water were eligible or did not contain E. coli bacteria. Whereas 51 samples $(54,3 \%)$ of drinking water did not meet the requirements or contained E.coli bacteria.

Quantitative Microbial Risk Assessment (QMRA)

3.1. Hazard Identification 
Escherichia coli is a bacterium that can be found in the environment, food, and intestines of humans and animals. E. coli is a large and diverse group of bacteria. Although most strains of E. coli are harmless and are an important part of the human digestive tract, several types of E. coli are pathogenic which means they can cause pain, for example, E. coli types O157: H7. Some types of E.coli can cause diarrhea, while others can cause urinary tract infections, respiratory diseases and pneumonia, and other diseases. Types of E.coli that can cause diarrhea can be transmitted through contaminated water or food, or contact with animals or humans. ${ }^{(9)}$

\subsection{Exposure Assessment}

The following is a distribution table for the calculation of exposure doses for research subjects in the Bandarharjo Village.

Table 3. Distribution of Value of Exposure Doses on Subjects in Bandarharjo Village

\begin{tabular}{cccc}
\hline & $\begin{array}{c}\text { E.coli } \\
\text { Consentration } \\
\text { (org/lt) }\end{array}$ & $\begin{array}{c}\text { Intake } \\
\text { Rate } \\
\text { (lt/day) }\end{array}$ & $\begin{array}{c}\text { Exposure } \\
\text { Dose } \\
\text { (org/day) }\end{array}$ \\
\hline Min & 0 & 2 & 0 \\
Max & 300 & 7,5 & 2250 \\
Mean & 130,6 & 1,63 & 212,9 \\
\hline
\end{tabular}

Table 3 above shows that the calculation of exposure dose values for each individual subject has an average of 212,9 organisms/day.

3.3. Dose-Response Assessment

The following is a distribution table for the calculation of the probability of infection per day for research subjects in Bandarharjo Village.

Table 4. Distribution of Probability of Infection per Day in Subjects in Bandarharjo Village

\begin{tabular}{cc}
\hline & Probability of Infection per Day \\
\hline Min & 0 \\
Max & $2,24 \times 10^{-4}$ \\
Mean & $2,12 \times 10^{-5}$ \\
\hline
\end{tabular}

Table 4 above shows that the calculation of the probability of infection per day in each subject has an average of $2,12 \times 10^{-5}$.

\subsection{Risk Characterization}

The following is a distribution table for the calculation of the probability of infection per year for research subjects in Bandarharjo Village.
Table 5. Distribution of Probability of Infection Per Year in Subjects in Bandarharjo District

\begin{tabular}{cc}
\hline & $\begin{array}{c}\text { Probability of Infection per } \\
\text { Year }\end{array}$ \\
\hline Min & 0 \\
Max & 0,078 \\
Mean & $7,7 \times 10^{-3}$ \\
Acceptable & \\
Risk & $10^{-4}(1$ infection $/ 10.000$ people $)$ \\
(US EPA) & \\
\hline
\end{tabular}

Table 5 above shows that the calculation of the probability of infection per year in each subject has an average of $7.7 \times 10^{-3}$. This value means the average infection per year is 77 infections/10,000 people, so it is greater than the acceptable risk limit value recommended by the US EPA, which is 1 infection/10,000 people.

\section{DISCUSSION}

In this study, the source of E. coli bacteria came from the environment (water). The water sample used is groundwater taken using a wellbore that has undergone a treatment process or has been cooked. The mechanism of exposure (intake) where E.coli makes contact with the host is through the oral route (ingestion) when a person consumes drinking water. However, a person's exposure mechanism can vary and does not only occur in one mechanism. For example, you can deliberately drink water (tap water that is not boiled), drink water accidentally (when swimming), swallow aerosols, and consume food. However, due to the lack of data sets regarding other exposure mechanisms, the analysis used only takes into account the exposure mechanism of someone who consumes boiled water. Besides, controls in this analysis are not taken into account. So the calculated pathogen concentration only comes from the source of exposure.

Previous research conducted by Hao Pang, et al (2017) examined the Quantitative Microbial Risk Assessment (QMRA) of E. coli bacteria in lettuce. The source of E.coli exposure studied came from fresh lettuce and the mechanism of exposure was through (oral) consumption. The controls taken into account in the risk assessment come from contamination from irrigation water, waiting time before harvest, contamination from the soil through harvesting equipment, lettuce washing, crosscontamination during the process, and the movement of the E.coli pathogen in lettuce. ${ }^{(10)}$

In the calculation of the probability of infection per day in 94 samples, the results show that the average value is $2.12 \times 10^{-5}$. Research conducted by Liang Zhou, et al (2014) has a smaller average probability of infection, 
which is $2.99 \times 10^{-10}$. The water sample used is drinking water that has been treated with an advanced water treatment process consisting of 4 stages, namely coagulation - sedimentation, rapid sand filtration (RSF), ozonation, and chlorine disinfection. ${ }^{(11)}$

The probability value of infection per day can be modified into other risk values, namely the probability of infection per year. In the calculation of the probability of infection per year in 94 samples, the results obtained that the average value is $7.7 \times 10^{-3}$. The value of the risk of infection per year acceptable for drinking water exposure to infectious agents determined by the US EPA is $10^{-4}$. This value means the risk of infection per year is 1 infection per 10,000 people. The average probability of infection per year in this study was $7.7 \times 10^{-3}$ or 77 infections per 10,000 people, which means it was greater than the specified limit value.

Research conducted by Liang Zhou, et al (2014) has results that are inversely proportional to this study. The average value of the probability of infection per year from the calculation results is $1.09 \times 10^{-7}$. This value is far below $10^{-4}$ infections/person/year which is an acceptable value of the risk of infection per year recommended by the US EPA. These results indicate that the drinking water treatment process in the study should be able to produce safe drinking water in terms of eliminating C. jejuni. ${ }^{(11)}$

Bacterial survival depends on several environmental factors such as humidity, temperature, $\mathrm{pH}$, the presence of oxygen and nutrients, and the availability of organic matter. Bacterial survival in water is related to water temperature. Research conducted by Tin, et al (2016) shows results that E.coli can survive at room temperature, $27^{\circ} \mathrm{C}$ for up to 8 days and maybe even more in conditions of nutrient deficiency in sterile water. Several other studies report that lower water temperatures can increase the ability of E.coli to survive under various water conditions. ${ }^{(12)}$

E. coli bacteria can survive and even grow in an open environment if available resources and the main favorable abiotic conditions. Both growth and death rates are determined by environmental conditions and how microorganisms can overcome this condition by regulating the expression patterns of their genes. In addition to its ability to obtain nutrients, some strains of E. coli produce fibrous structures that extend to help cells stick to the surface and can form colonies (for example, plant surfaces). Therefore, E. coli cannot be easily washed from plant parts or removed by disinfecting and washing. ${ }^{(13)}$

In general, organisms will die from time to time in a very carbon-limited environment. However, E.coli O157: $\mathrm{H} 7$ can survive and even grow in sterile freshwater at low carbon concentrations. E.coli can adapt quickly and tolerate diverse stress conditions. E. coli can enter the "dormant" state (inactive). In this case, cells cannot be easily recovered on standard laboratory media, but they still exist as viable cells. ${ }^{(13)}$

The exposure routes identified in this study were by mouth or ingestion and the E. coli source identified was drinking water from a wellbore (groundwater). However, the route of exposure of a pathogen can vary. Apart from ingestion by consuming drinking water, the route of exposure to E.coli can also occur when accidentally swallowing water while bathing or swimming. So that infection can occur not only from factors that have been identified, but can also occur from other factors that are not identified.

\section{CONCLUSION}

Risk assessment has shown that community drinking water has not been able to reach the target of infection risk per year by the US EPA, which is $10^{-4}$. The majority of the people are at risk of being infected with Escherichia coli bacteria. Boiling water is an optional treatment at the household level to kill microorganisms in the water. Boiled water must be stored in a place that can maintain the temperature of the water because boiled water can become recontaminated once it has cooled. Safe storage of drinking water can eliminate sources of recontamination by keeping objects, including hands, out of the system. Practicing good personal hygiene at the household level can reduce recontamination to food and drinking water.

\section{REFERENCES}

[1] Prihatin RB, Suryani AS, Qodriyatun SN, Prasetiawan T, Winurini S PU. Provision of Clean Water in Indonesia: The Role of the Government, Local Governments and Communities. Jakarta: Center for Assessment, Data Processing, and Information (PD3I) dan Azza Grafika; 2015.

[2] The Regulation of the Minister of Health of the Republic of Indonesia Number 416/MEN.KES/PER/IX/1990. Concerning Requirements and Supervision of Water Quality.

[3] Centers for Disease Control and Prevention. Assessing Access to Water \& Sanitation [Internet]. 2017 [cited 2019 Dec 6]. Available from: https://www.cdc.gov/healthywater/global/assessing.html

[4] George L, Jack VDV, Yvonne H, Alimamy KK, Sampson OK, Jan WAF. Microbial Groundwater Quality Status of Hand-Dug Wells and Boreholes in the Dodowa Area of Ghana. Int J Env Res Public Heal. 2018;15(4).

[5] Bob B, Nga DLC, Jennifer M, Ken W. Water wells that last for generations. Edmonton; 2010.

[6] Alexander A, Julius T, Andrew T, Ezera A, Christine A. Contamination Potentials of Household Water Handling and Storage Practices in Kirundo Sub Country, Kisoro District, 
Uganda. J Environ Public Health. 2019;1-8.

[7] World Health Organization. Guidelines for drinking water quality: fourth edition incorporating the first addendum. Geneva; 2017.

[8] US Department of Agriculture/Food Safety and Inspection Service (USDA/FSIS), US Environmental Protection Agency (EPA). Microbial Risk Assessment Guideline: Pathogenic Organisms with Focus on Food and Water. 2012;

[9] Centers for Disease Control and Prevention. E.coli (Escherichia coli) [Internet]. 2014 [cited 2019 Jun 18]. Available from: https://www.cdc.gov/ecoli/general/index.html

[10] Hao P, Elisabetta L, Robert LB, Donald WS, Abani KP. Quantitative Microbial Risk Assessment for Escherichia coli O157:H7 in Fresh-Cut Lettuce. J Food Prot. 2017;80(2):302-11.

[11] Liang Z, Shinya E, Yumiko O, Sadahiko I. Quantitative microbial risk assessment of drinking water treated with advanced water treatment process. J Water Supply Res Technol - AQUA. 2014;114-23.

[12] Tin SA, Sitti JBR, Khin SO, Zaw L, Helen M. The Study on the Survival of Escherichia coli in Water at Room Temperature. Borneo J Med Sci. 2016;10(1):14-8.

[13] Jan DvE, Alexander VS, Rodrigo C, Jack TT. Survival of Escherichia coli in the environment : fundamental and public health aspects. ISME J. 2011;5(2):173-83. 